\title{
Application of The Discovery Learning Model Assisted by Google Meet to Improve Students' Critical Thinking Skills and Science Learning Outcomes
}

\section{Galih Mustikaningrum ${ }^{1}{ }^{*}$, Widiyanto ${ }^{2}$, Nani Mediatati ${ }^{3}$}

${ }^{1}$ Satya Wacana Christian University, Indonesia

2,3 State University of Semarang, Indonesia

\begin{tabular}{l} 
A R T I C L E I N F O \\
\hline Article history: \\
25 December 2020 \\
Received in revised form \\
01 January 2021 \\
Accepted 25 January \\
2021 \\
Available online 03 \\
Pebruari 2021 \\
\hline
\end{tabular}

Kata Kunci:

Berpikir Kritis, Hasil

Belajar

Keywords:

Critical Thingking,

Learning Outcomes

\begin{abstract}
A B S T R A K
Situasi pandemi Covid-19 menyebabkan terkendalanya proses pelaksanaan pembelajaran. Hal tersebut dapat memberikan pengaruh negatif terhadap kualitas output pembelajaran IPA. Penelitian ini bertujuan untuk mendeskripsikan keterampilan berpikir kritis dan hasil belajar IPA melalui penerapan model pembelajaran discovery learning berbantuan aplikasi Google Meet. Jenis penelitian ini yaitu Penelitian Tindakan Kelas (PTK) yang terdiri dari empat tahap, yaitu perencanaan, pelaksanaan, observasi, dan refleksi. Subjek dalam penelitian ini berjumlah 15 siswa. Instrumen penelitian yang digunakan adalah lembar observasi keterampilan berpikir kritis dan lembar tes hasil belajar. Hasil penelitian menunjukkan bahwa keterampilan berpikir kritis pada tahap pra siklus 52,33, siklus I 60,17 , dan siklus II 69,17. Lalu, ketuntasan hasil belajar siswa pada pra siklus $60,00 \%$, siklus I $73,33 \%$, dan siklus II $86,67 \%$. Berdasarkan hal tersebut dapat disimpulkan bahwa pembelajaran dengan model discovery learning berbantuan aplikasi Google Meet dapat meningkatkan keterampilan berpikir kritis dan hasil belajar IPA. Hasil penelitian ini berimplikasi pada penemuan solusi untuk meningkatkan kualitas output pembelajaran IPA.
\end{abstract}

\section{A B S T R A C T}

The Covid-19 pandemic situation has hampered the learning process. This can have a negative effect on the quality of the science learning output. This study aims to describe critical thinking skills and science learning outcomes through the application of the discovery learning model assisted by the Google Meet application. This type of research is Classroom Action Research (PTK) which consists of four stages, namely planning, implementing, observing, and reflecting. The subjects in this study were 15 students. The research instrument used was the critical thinking skills observation sheet and the learning outcome test sheet. The results showed that critical thinking skills in the pre-cycle stage were 52.33, cycle I 60.17, and cycle II 69.17. Then, the completeness of student learning outcomes in the precycle is $60.00 \%$, the first cycle is $73.33 \%$, and the second cycle is $86.67 \%$. Based on this, it can be concluded that learning with the discovery learning model assisted by the Google Meet application can improve critical thinking skills and science learning outcomes. The results of this study have implications for finding solutions to improve the quality of science learning output.

\section{Introduction}

Regulation of the Minister of Health No. 9 Year 2020, states that in an effort to deal with Covid-19, the minister of health has set large-scale social restrictions (PSBB). Almost all outdoor activities had been limited, one of which was learning activities (Sadikin \& Hamidah, 2020; Wijayanengtias \& Claretta, 2020). During the period of large-scale social restrictions (PSBB), teaching and learning activities were carried out online (Dewi, 2020; Purwanto et al., 2020; Sadikin \& Hamidah, 2020; Setyorini, 2020; Susilowati, 2020). The role of online-based learning as a support for the learning process made it easier for students to adapt to current technology (Abidah et al., 2020; Cahyani et al., 2020; Sujarwo et al., 2020). Online learning is expected to have a positive impact on students and the progress of education in Indonesia. In this case, teachers also expect the participation and care of parents at home to encourage their children to be enthusiastic about learning at home, using existing facilities, and carrying out activities in accordance 
with government regulations during the Covid-19 occurrence (Almaiah et al., 2020; Cho \& Hong, 2021; Zaharah et al., 2020).

In online learning, students can become less active in conveying their aspirations and thoughts, which can lead to saturated learning and progress in learning outcomes (Rimbarizki \& Susilo, 2017). This situation also occurred in teaching and learning activities at SDN 2 Limbangan. The results of interviews conducted with several teachers stated that during online learning student learning outcomes decreased, only a few participated during the learning process. The learning process that occured at SDN 2 Limbangan had not applied a model that was able to improve critical thinking skills, and this had an impact on low student learning outcomes. The average score of daily assessments on science subject content had only reached 60.00 and Indonesian Language 62.00. The percentage of the number of students who had achieved mastery learning in science subject content had only reached $60.00 \%$, and the Indonesian language content had only reached $63.00 \%$.

There are several factors that affected the decline in student learning outcomes during the Covid19 pandemic, namely student characteristics and learning environment conditions. For example, the difficulty of students finding the right time to study at home, lack of facilities for online learning (Nakayama et al., 2007). This situation certainly has an impact on the quality of learning for students and teachers. Teachers are required to provide good teaching, create a conducive atmosphere for learning and creatively and innovatively use attractive learning media so that students can understand learning material and learning objectives can be achieved (Utami, 2013). One solution that can be applied is with an innovative online-based learning model.

The application of the Google Meet assisted discovery learning model is one of the breakthroughs in addressing the current pandemic. Learning activities that cannot take place face-to-face can be circumvented by using the Google Meet application (Wahyuni, 2021). The use of this application can help teachers deliver material and provide assignments and guidance to students so that the problem of critical thinking skills and low student learning outcomes can be overcome (Nurhayati et al., 2020; Wahyuni, 2021).

Several previous studies have discussed the effect of discovery learning models on critical thinking and science learning outcomes. First, research conducted by Pamungkas et al. (2019) show that the discovery learning model has a positive effect on improving the process and student learning outcomes. In addition, Kartikaningtyas et al. (2017) argued that discovery learning can be used to develop students' critical thinking skills. Patrianingsih \& Kaseng (2016) also stated that learning by applying the discovery learning model had a positive impact on student learning outcomes and understanding of learning material.

Previous studies only examined the use of discovery learning models in face-to-face learning. There are no studies that have applied this model in online learning and integrated it with digital platforms that support the online learning process. This is important to do considering that the Covid-19 pandemic situation requires a learning process to be carried out online to reduce the risk of increasing Covid-19 cases (Bozkurt et al., 2020; Xue et al., 2021).

This study aims to describe the improvement of critical thinking skills and science learning outcomes through the application of the discovery learning learning model assisted by Google Meet in grade IV SDN 2 Limbangan students.

\section{Method}

The type of research used was Classroom Action Research which consists of four stages, namely: planning, implementing, observing, and reflecting (Arikunto, 2006). The research design is presented in Figure 1. 


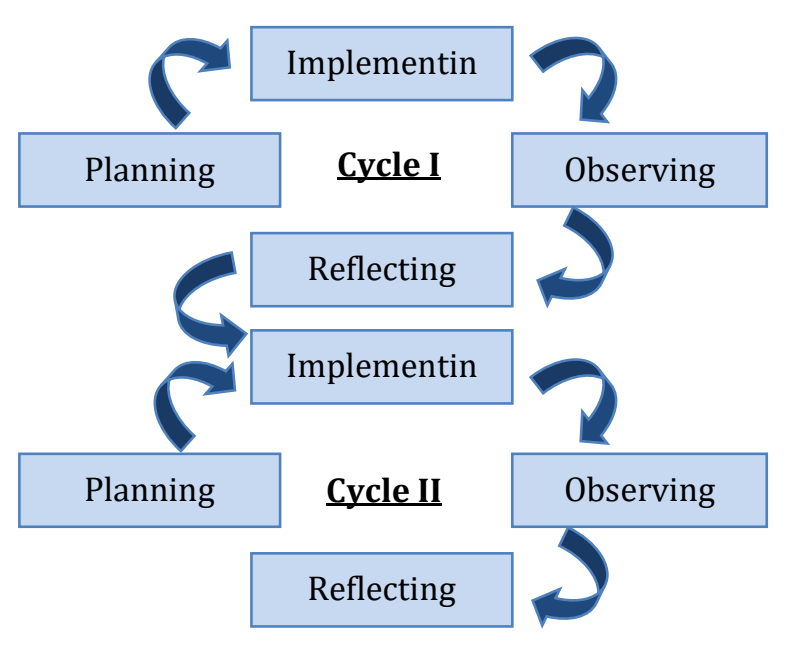

Figure 1. Classroom Action Research Design

This research was conducted at SDN 2 Limbangan, Limbangan District, Kendal Regency, with the research subjects totaling 15 fourth grade students (11 male students and 4 female students). The research instrument used was the critical thinking skills observation sheet, and learning outcome test sheet. The data analysis technique was carried out by descriptive quantitative.

\section{Result and Discussion}

\section{Results}

Pre Cycle

Observation of students critical thinking skills before taking action, obtained data on students critical thinking skills in Table 1.

Table 1. The Frequency Of Students' Pre-Cycle Critical Thinking Skills

\begin{tabular}{cccc}
\hline Interval & Frequency & Percentage & Category \\
\hline $81-100$ & 0 & $0.00 \%$ & Very Critical \\
$66-80$ & 1 & $6.67 \%$ & Critical \\
$56-65$ & 4 & $26.67 \%$ & Quite Critical \\
$41-55$ & 6 & $40.00 \%$ & Less Critical \\
$0-40$ & 4 & $26.67 \%$ & Uncritical \\
Amount & 15 & $100.00 \%$ & \\
\hline
\end{tabular}

Referring to the table above, it is known that 1 student (6.67\%) obtained the critical category, 4 students (26.67\%) obtained the critical enough category, 6 students $(40.00 \%)$ got the less critical category and 4 students (26.67\%) got the uncritical category. The average score of students' critical thinking skills was 52.33 in the less critical category. This shows that most students have low critical thinking skills. Meanwhile, the frequency of student learning outcomes in pre-cycle can be presented in Table 2.

Table 2. The Frequency of Pre-Cycle Student Learning Outcomes

\begin{tabular}{cccc}
\hline Interval & Frequency & Percentage & Category \\
\hline $90-100$ & 0 & $0.00 \%$ & Very well \\
$80-89$ & 1 & $6.67 \%$ & Good \\
$70-79$ & 8 & $53.33 \%$ & Enough \\
$60-69$ & 1 & $6.67 \%$ & Less \\
$0-59$ & 5 & $33.33 \%$ & Very less \\
Amount & 15 & $100.00 \%$ & \\
\hline
\end{tabular}


Based on Table 2, it is known that 1 student (6.67\%) obtained learning outcomes in good category, 8 students (53.33\%) in enough category, 1 student $(6.67 \%)$ in less category, and 5 students $(33.33 \%)$ with very less category. In detail, the analysis of student learning outcomes in pre-cycle learning is presented in Table 3 below.

Table 3. Analysis of Pre-Cycle Student Learning Outcomes

\begin{tabular}{lcc}
\hline \multicolumn{1}{c}{ Student Learning Completeness } & Total students & $\begin{array}{c}\text { The Percentage of Student } \\
\text { Learning Completeness }\end{array}$ \\
\hline Completed & 9 & $60.00 \%$ \\
Not finished yet & 6 & $40.00 \%$ \\
Amount & 15 & $100.00 \%$ \\
\hline
\end{tabular}

Based on the results of the competency test, it can be seen that the percentage of student learning completeness shows that out of a total of 15 students there are 9 students or $60.00 \%$ scored $\geq 70.00$ complete learning while 6 students or $40.00 \%$ have not finished learning by getting a score below the minimum learning completeness which has been determined, amounting to 70.00 .

\section{Cycle I}

The results of students' critical thinking skills in Cycle I in learning theme "The beauty of diversity in my country", sub-theme 1, on the content of science lessons, cycle I can be seen in Table 4.

Table 4. The Frequency of Students' Critical Thinking Skills in Cycle I

\begin{tabular}{cccc}
\hline Interval & Frequency & Percentage & Category \\
\hline $81-100$ & 1 & $6.67 \%$ & Very Critical \\
$66-80$ & 4 & $26.67 \%$ & Critical \\
$56-65$ & 4 & $26.67 \%$ & Quite Critical \\
$41-55$ & 5 & $33.33 \%$ & Less Critical \\
$0-40$ & 1 & $6.67 \%$ & Uncritical \\
Amount & 15 & $100.00 \%$ & \\
\hline
\end{tabular}

Referring to Table 4, it is known that 1 student (6.67\%) obtained very critical category, 4 students (26.67\%) obtained critical category, 4 students (26.67\%) got quite critical category, 5 students (33.33\%) got less critical category and 1 student (6.67\%) got uncritical category. The average score of students' critical thinking skills in the first cycle was 60.50 with a fairly critical category. This showed an increase in students' critical thinking skills in learning cycle I.

Furthermore, student learning outcomes in learning theme "The Beauty of Diversity in My Country" sub-theme 1, on the content of science lessons, can be seen from the results of student competency tests in Table 5.

Table 5. The Frequency of Student Learning Outcomes in Cycle I

\begin{tabular}{cccc}
\hline Interval & Frequency & Percentage & Category \\
\hline $90-100$ & 2 & $13.33 \%$ & Very well \\
$80-89$ & 4 & $26.67 \%$ & Good \\
$70-79$ & 5 & $33.33 \%$ & Enough \\
$60-69$ & 3 & $20.00 \%$ & Less \\
$0-59$ & 1 & $6.67 \%$ & Very less \\
\hline
\end{tabular}

Based on Table 5, it is known that there are 4 students (26.67\%) obtained learning outcomes in good category, 5 students (33.33\%) are in enough category, 3 students $(20.00 \%)$ are in less category, and 1 student $(6.67 \%)$ with very less category. In detail, the analysis of student learning outcomes in cycle I learning is presented in Table 6 below. 
Table 6. Analysis of Student Learning Outcomes in Cycle I

\begin{tabular}{lcc}
\hline \multicolumn{1}{c}{ Student Learning Completeness } & Total students & $\begin{array}{c}\text { The Percentage of Student } \\
\text { Learning Completeness }\end{array}$ \\
\hline Completed & 11 & $73.33 \%$ \\
Not finished yet & 4 & $26.67 \%$ \\
Amount & 15 & $100.00 \%$ \\
\hline
\end{tabular}

Based on the results of the competency test, it can be seen that the implementation of the first cycle of learning has not been completed with the class average score reaching 71.33. The percentage of student learning completeness shows that out of a total of 15 students there are 11 students or $73.33 \%$ who have scored $\geq 70.00$ complete learning while 4 students or $26.67 \%$ have not finished learning by getting a score below the predetermined minimum learning completeness, amounting to 70.00 .

\section{Cycle II}

The results of students' critical thinking skills in cycle II in learning theme "The beauty of diversity in my country", sub-theme 1, on content of science lessons, cycle I can be seen in Table 7.

Table 7. The Frequency of Students' Critical Thinking Skills in Cycle II

\begin{tabular}{cccc}
\hline Interval & Frequency & Percentage & Category \\
\hline $81-100$ & 2 & $13,33 \%$ & Very Critical \\
$66-80$ & 5 & $33.33 \%$ & Critical \\
$56-65$ & 5 & $33.33 \%$ & Quite Critical \\
$41-55$ & 3 & $20.00 \%$ & Less Critical \\
$0-40$ & 0 & $0.00 \%$ & Uncritical \\
Amount & 15 & $100.00 \%$ & \\
\hline
\end{tabular}

Referring to Table 7, it is known that there are 2 students $(13.33 \%)$ obtained very critical category, 5 students (33.33\%) obtained critical category, 5 students (33.33\%) got critical enough category, and 3 students $(20.00 \%)$ received less critical category. The average score of students' critical thinking skills in cycle II was 69.17 with critical category. This showed an increase in students' critical thinking skills in cycle II learning.

Furthermore, student learning outcomes in learning theme "The Beauty of Diversity in My Country" sub-theme 1, on content of science lessons, can be seen from the results of student competency tests in Table 8.

Table 8. The Frequency of Student Learning Outcomes in Cycle II

\begin{tabular}{cccc}
\hline Interval & Frequency & Percentage & Category \\
\hline $90-100$ & 5 & $33.33 \%$ & Very well \\
$80-89$ & 5 & $33.33 \%$ & Good \\
$70-79$ & 3 & $20.00 \%$ & Enough \\
$60-69$ & 2 & $13.33 \%$ & Less \\
$0-59$ & 0 & $0.00 \%$ & Very less \\
\hline
\end{tabular}

Based on Table 8, it is known that there are 5 students (33.33\%) obtained very good learning outcomes, 5 students (33.33\%) obtained good learning outcomes, 3 students $(20.00 \%)$ received enough categories, 2 students (13.33\%) with less category. In detail, the analysis of student learning outcomes in second cycle of learning the researcher presents in Table 9 below. 
Table 9. Analysis of Student Learning Outcomes in Cycle II

\begin{tabular}{lcc}
\hline Student Learning Completeness & Total students & $\begin{array}{c}\text { The Percentage of Student } \\
\text { Learning Completeness }\end{array}$ \\
\hline Completed & 13 & $86.67 \%$ \\
Not finished yet & 2 & $13.33 \%$ \\
Amount & 15 & $100.00 \%$ \\
\hline
\end{tabular}

Based on the results of the competency test, it can be seen that the implementation of second cycle of learning has been completed with a class average score of 80.67. The percentage of student learning completeness shows that out of a total of 15 students there are 13 students or $86.67 \%$ who scored $\geq 70.00$ completed learning while 2 students or $13.33 \%$ had not finished learning.

The improvement of students' critical thinking skills based on the average score from pre-cycle to cycle II can be seen in Table 10 below.

Table 10. Comparison of Improvement of Students' Critical Thinking Skills

\begin{tabular}{|c|c|c|}
\hline Learning & Average & Category \\
\hline Pre Cycle & 52.33 & Less Critical \\
\hline Cycle I & 60.50 & Critical Enough \\
\hline Cycle II & 69.17 & Critical \\
\hline
\end{tabular}

The improvement of student learning outcomes based on the percentage of learning completeness from pre-cycle to cycle II is presented in Table 11 below.

Table 11. Comparison of The Percentage of Student Learning Completeness

\begin{tabular}{lccc}
\hline \multicolumn{1}{c}{ Learning } & \multicolumn{2}{c}{ Percentage of Completion of Learning } & Information \\
\cline { 1 - 3 } & Not Complete & Complete & \\
\hline Pre Cycle & $40.00 \%$ & $60.00 \%$ & Low \\
Cycle I & $26.67 \%$ & $73.33 \%$ & Increase \\
Cycle II & $13.33 \%$ & $86.67 \%$ & Increase \\
\hline
\end{tabular}

The data above shows that students' learning completeness from pre-cycle to cycle II has increased. This can be proven from the increase in student learning outcomes. The increase in learning outcomes is due to the fact that students were more enthusiastic and serious about participating in learning activities in each cycle. The review above shows that the improvement of learning has been successful, so there is no need to continue in the next cycle.

\section{Discussion}

The results showed that learning theme "The Beauty of Diversity in My Country" sub-theme 1 on science subject content had increased. The application of Google Meet assisted discovery learning model was running well because it could meet the needs of students who were prepared before learning process. The use of the Discovery Learning model can also facilitate and provide direct experience for both students and teachers, so that learning will be more meaningful according to the material that has been taught to students (Agustihana \& Suparno, 2018; Prasasti et al., 2019). In discovery learning model, there is a description of learning objectives, students and their groups can work together, exchange ideas in solving problems, present the results of discussions and direct in providing conclusions. This supports students to be able to learn independently, be active, creative, and think critically (Khofiyah, Santoso, \& Akbar, 2019; Prasasti, Koeswanti, \& Giarti 2019). In discussion activities, students express opinions and exchange ideas which result in practicing critical thinking skills (Grussendorf \& Rogol, 2018). So, at this stage the teacher plays a role in motivating students to be active in discussions.

There are several factors that affected the decline in student learning outcomes during the Covid19 pandemic, namely student characteristics and learning environment conditions. For example, the difficulty of students finding the right time to study at home, lack of facilities for online learning (Dwivedi et al., 2020; Nakayama et al., 2007). This situation certainly has an impact on the quality of learning for students and teachers. Teachers are required to provide good teaching, create a conducive atmosphere for 
learning and creatively and innovatively use attractive learning media so that students can understand learning material and learning objectives can be achieved (Anugrahana, 2020; Utami, 2013).

The application of the Google Meet assisted discovery learning model is one of the breakthroughs in addressing the current pandemic. Learning activities that cannot take place face-to-face can be circumvented by using the Google Meet application (Basilaia \& Kvavadze, 2020; Simamora, 2020; Wahyuni, 2021). The use of this application can help teachers deliver material and provide assignments and guidance to students so that the problem of critical thinking skills and low student learning outcomes can be overcome (Nurhayati et al., 2020; Wahyuni, 2021).

\section{Conclusion}

The application of Google Meet assisted discovery learning model was running well because it could meet the needs of students who were prepared before learning process. The use of the Discovery Learning model can also facilitate and provide direct experience for both students and teachers, so that learning will be more meaningful according to the material that has been taught to students. In discovery learning model, there is a description of learning objectives, students and their groups can work together, exchange ideas in solving problems, present the results of discussions and direct in providing conclusions. This supports students to be able to learn independently, be active, creative, and think critically. In discussion activities, students' express opinions and exchange ideas which result in practicing critical thinking skills. So, at this stage the teacher plays a role in motivating students to be active in discussions.

\section{References}

Abidah, A., Hidaayatullaah, H. N., Simamora, R. M., Fehabutar, D., \& Mutakinati, L. (2020). The Impact of Covid-19 to Indonesian Education and Its Relation to the Philosophy of "Merdeka Belajar." Studies in Philosophy of Science and Education, 1(1), 38-49. https://doi.org/https://doi.org/10.46627/sipose.v1i1.9.

Agustihana, S., \& Suparno. (2018). Effectiveness of Physics Mobile Learning Media to Improve Higher Order Thinking Skills of Students in Thermodynamics. Journal of Physics: Conference Series, 1097(1). https://doi.org/10.1088/1742-6596/1097/1/012031.

Almaiah, M. A., Al-Khasawneh, A., \& Althunibat, A. (2020). Exploring the critical challenges and factors influencing the E-learning system usage during COVID-19 pandemic. Education and Information Technologies, 25(6), 5261-5280. https://doi.org/10.1007/s10639-020-10219-y..

Anugrahana, A. (2020). Hambatan, Solusi dan Harapan: Pembelajaran Daring Selama Masa Pandemi Covid-19 Oleh Guru Sekolah Dasar. Scholaria: Jurnal Pendidikan Dan Kebudayaan, 10(3), 282-289. https://doi.org/10.24246/j.js.2020.v10.i3.p282-289.

Arikunto, S. (2006). Metode Penelitian Kualitatif. Bumi Aksara.

Basilaia, G., \& Kvavadze, D. (2020). Transition to Online Education in Schools during a SARS-CoV-2 Coronavirus (COVID-19) Pandemic in Georgia. Pedagogical Research, 5(4). https://doi.org/10.29333/pr/7937.

Bozkurt, A., Jung, I., Xiao, J., Vladimirschi, V., Schuwer, R., Egorov, G., Lambert, S., Al-Freih, M., Pete, J., Olcott Jr., D., Rodes, V., Aranciaga, I., Bali, M., Alvarez Jr., A., Roberts, J., Pazurek, A., Raffaghelli, J., Panagiotou, N., de Coëtlogon, P., ... Paskevicius, M. (2020). A global outlook to the interruption of education due to COVID-19 Pandemic: Navigating in a time of uncertainty and crisis. Asian Journal of Distance Education, 15(1), 1-126. https://doi.org/10.5281/zenodo.3878572.

Cahyani, A., Listiana, I. D., \& Larasati, S. P. D. (2020). Motivasi Belajar Siswa SMA pada Pembelajaran Daring di Masa Pandemi Covid-19. IQ (Ilmu Al-Qur'an): Jurnal Pendidikan Islam, 3(01), 123-140. https://doi.org/https://doi.org/10.37542/iq.v3i01.57.

Cho, M. J., \& Hong, J. P. (2021). The emergence of virtual education during the COVID-19 pandemic: The past, present, and future of the plastic surgery education. Journal of Plastic, Reconstructive and Aesthetic Surgery, xxxx. https://doi.org/10.1016/j.bjps.2020.12.099.

Dewi, W. A. F. (2020). Dampak Covid-19 Terhadap Implementasi Pembelajaran Daring Di Sekolah Dasar. Jurnal Ilmu Pendidikan, 2(1), 55-61. https://doi.org/https://doi.org/10.31004/edukatif.v2i1.89.

Dwivedi, Y. K., Hughes, D. L., Coombs, C., Constantiou, I., Duan, Y., Edwards, J. S., Gupta, B., Lal, B., Misra, S., Prashant, P., Raman, R., Rana, N. P., Sharma, S. K., \& Upadhyay, N. (2020). Impact of COVID-19 pandemic on information management research and practice: Transforming education, work and life. International Journal of Information Management, 55, 102211. 
https://doi.org/10.1016/j.ijinfomgt.2020.102211.

Grussendorf, J., \& Rogol, N. C. (2018). Reflections on Critical Thinking: Lessons from a Quasi-Experimental Study. Journal of Political Science Education, 14(2), 151-166. https://doi.org/https://doi.org/10.1080/15512169.2017.1381613.

Kartikaningtyas, V., Kusmayadi, T. A., \& Riyadi. (2017). Contextual Approach with Guided Discovery Learning and Brain Based Learning in Geometry Learning. Journal of Physics: Conference Series, 895(1). https://doi.org/10.1088/1742-6596/895/1/012024.

Khofiyah, H. N., Santoso, A., \& Akbar, S. (2019). Pengaruh Model Discovery Learning Berbantuan Media Benda Nyata terhadap Kemampuan Berpikir Kritis dan Pemahaman Konsep IPA. Jurnal Pendidikan: Teori, Penelitian, Dan Pengembangan, 4(1), 61-67. https://doi.org/https://doi.org/10.1080/15332276.2014.11678425.

Nakayama, M., Yamamoto, H., \& Santiago, R. (2007). Relationship between learner characteristics and learning performance in hybrid courses among Japanese students. Elektronic Journal ELearning, 5(3), 195-206. https://doi.org/http://dx.doi.org/10.4018/IJDET.2016010105.

Nurhayati, S., Wicaksono, M. F., Lubis, R., Rahmatya, M. D., \& Hidayat, H. (2020). Peningkatan Kemampuan Guru Dalam Pembelajaran Daring Dengan Memanfaatkan Teknologi Informasi Bagi Guru SMA Negeri 5 Cimahi Bandung. Indonesian Community Service and Empowerment (IComSE), 1(2), 7076. https://doi.org/https://doi.org/10.34010/icomse.v1i2.3878.

Pamungkas, G. H., Harjono, N., \& Airlanda, G. S. (2019). Peningkatan Proses Dan Hasil Belajar Ipa Kelas 5 Tema 6 Subtema 3 Dengan Model Pembelajaran Discovery Learning. Jurnal Basicedu, 3(1), 43-46. https://doi.org/10.31004/basicedu.v3i1.64.

Patrianingsih, E. A., \& Kaseng, E. S. (2016). Model Pembelajaran Discovery Learning, Pemahaman Konsep Biologi, dan Sikap Ilmiah Peserta Didik. Jurnal Penelitian Pendidikan Insani, 19(2), 74-86.

Prasasti, D. E., Koeswanti, H. D., \& Giarti, S. (2019). Peningkatan Keterampilan Berpikir Kritis Dan Hasil Belajar Matematika Melalui Model Discovery Learning Di Kelas IV SD. Jurnal Basicedu, 3(1), 174179. https://doi.org/https://doi.org/10.31004/basicedu.v3i1.113.

Purwanto, A., Pramono, R., Asbari, M., Santoso, P. B., Wijayanti, L. M., Hyun, C. C., \& Putri, R. S. (2020). Studi Eksploratif Dampak Pandemi COVID-19 Terhadap Proses Pembelajaran Online di Sekolah Dasar. Journal Og Education, Psychology and Counseling, 2(1-12). https://ummaspul.ejournal.id/Edupsycouns/article/view/397..

Rimbarizki, R., \& Susilo, H. (2017). Penerapan Pembelajaran Daring Kombinasi Dalam Meningkatkan Motivasi Belajar Peserta Didik Paket C Vokasi Di Pusat Kegiatan Belajar Masyarakat (Pkbm) Pioneer Karanganyar. J+Plus Unesa, 6(2), 1-12.

Sadikin, A., \& Hamidah, A. (2020). Pembelajaran Daring di Tengah Wabah Covid-19. Jurnal Ilmiah Pendidikan Biologi, 6(02), 214-224. https://doi.org/10.22437/bio.v6i2.9759.

Setyorini, I. (2020). Terhadap Proses Pembelajaran Pada Kurukulum 13 ? Jiemar: Journal of Industrial Engineering \& Management Research, 01(Juni), 95-102. https://doi.org/https://doi.org/10.7777/jiemar.v1i1.

Simamora, R. M. (2020). The Challenges of Online Learning during the COVID-19 Pandemic: An Essay Analysis of Performing Arts Education Students. Studies in Learning and Teaching, 1(2), 86-103. https://doi.org/10.46627/silet.v1i2.38.

Sujarwo, S., Sukmawati, S., Akhiruddin, A., Ridwan, R., \& Suharti Siradjuddin, S. S. (2020). An Analysis of University Students' Perspective On Online Learning in The Midst of Covid-19 Pandemic. Jurnal Pendidikan Dan Pengajaran, 53(2), 125. https://doi.org/10.23887/jpp.v53i2.24964.

Susilowati, E. (2020). Bagaimana Pembelajaran Daring di Tengah Wabah Covid 19 melalui Grup WhatsApp? Jurnal Pendidikan Matematika Raflesia, 05(03), 1-25. https://doi.org/https://doi.org/10.33449/jpmr.v5i3.12896.

Utami, Y. S. (2013). Peran Guru Dalam Menciptakan Pembelajaran Alam Kelas V Di Sekolah Dasar Negeri Kranggan 2 Kota Mojokerto. Universitas Islam Negeri Maulana Malik Ibrahim.

Wahyuni, V. N. (2021). Efektifitas Penggunaan Google Meet Dalam Pembelajaran Daring Terhadap Peningkatan Hasil Belajar Siswa Kelas V SD Al-Islam Plus Krian Sidoarjo. UIN Sunan Ampel.

Wijayanengtias, M., \& Claretta, D. (2020). Student Perceptions of Online Learning During the Covid-19 Pandemic. Kanal: Jurnal Ilmu Komunikasi, 9(1), 16-21. https://doi.org/10.21070/kanal.v9i1.685. 
Xue, Q., Xie, X., Liu, Q., Zhou, Y., Zhu, K., Wu, H., Wan, Z., Feng, Y., Meng, H., Zhang, J., Zuo, P., \& Song, R. (2021). Knowledge, attitudes, and practices towards COVID-19 among primary school students in Hubei Province, China. Children and Youth Services Review, 120(November 2020), 105735. https://doi.org/10.1016/j.childyouth.2020.105735.

Zaharah, Kirilova, G. I., \& Windarti, A. (2020). Impact of Corona Virus Outbreak Towards Teaching and Learning Activities in Indonesia. Salam: Jurnal Sosial Dan Budaya Syar'i, 7(3), 269-282. https://doi.org/http://doi.org/10.15408/sjsbs.v7i3.15104. 